\title{
A kolozsvári matematikai iskola kialakulása (Száz éve már, több is talán...)
}

\section{Kolumbán József}

The Development of the Kolozsvar (Cluj) School of Mathematics (A hundred years ago, even more...) - In this paper we deal with the development of the School of Mathematics in Cluj (Kolozsvar) at the end of the 19th century and the beginning of the 20th century. It is remarkable that among Hungarian universities the University of Cluj was the first to become an important centre of mathematics, and not the one in Budapest. During the decades preceding the world war the school of mathematics in Cluj became one of the best centers of mathematics in the Monarchy. Its representatives gained imperishable merits for themselves and for the Hugarian scientific life. It is not probable that a week passes without mentioning somewhere in the world the name of Gyula Farkas, Lipót Fejér, Alfréd Haar or Frigyes Riesz. How did Mathematics in Cluj reach so high at the beginning of the 20th century? What personal conditions, social and economic facts, strategies aiming the scientific life and the development of education contributed to this development? The paper tries to answer these questions.

\section{Prológus}

Bolyai János születésének századik évfordulója alkalmával a Kolozsváron rendezett ünnepi megemlékezésen a Magyar Tudományos Akadémia elnöksége bejelentette a Bolyai-díj létrehozását, melyet ötévenként szándékoztak odaítélni annak a matematikusnak, aki az előző években a kutatásban kimagasló eredményeket ért el. Elsőként ezt a díjat 1905-ben Henri Poincaré francia matematikus nyerte el. Ezzel kapcsolatban Gergely Jenő, aki Riesz Frigyes tanítványa volt, majd a Bolyai Tudományegyetem tanára lett, a következő történetet mesélte: „A Keleti Pályaudvaron a magyar tudományos élet számos kiválósága izgatottan várta a párizsi gyors érkezését. A 
kor egyik legnagyobb tudósa jött Budapestre, hogy átvegye a Bolyai-díjat. Az állomáson az üdvözlő szavak elhangzása után megszólalt Poincaré is: - Hol van Fözsé? - kérdezte. A magyarok zavartan néztek össze. Ki lehet az a Fözsé? Hamarosan rájöttek, hogy Fejér Lipótról, a kolozsvári egyetem tanáráról van szó, aki 25 éves kora ellenére az akkori idők egyik legismertebb magyar matematikusa volt. A trigonometrikus sorokra vonatkozó úttörő eredménye alig húszéves korában a párizsi Comptes Rendus-ben jelent meg. $\mathrm{Az}$ ott közölt Fejér-féle összegezési eljárás a Fourier-sorok reneszánsza kiinduló pontjának bizonyult. Ugyanabban az időben kezdte el Fejér azokat a kutatásokat, amelyek jelentősen gazdagították a klasszikus polinomokra vonatkozó ismereteket. Egy új, talán a legegyszerủbb bizonyítását adta a Weierstrass-féle approximációs tételnek, majd megindította a Csebisevpolinomokkal kapcsolatos nagyhatású vizsgálatait. Ettől kezdve a legismertebb folyóiratok rendszeresen közöltek Fejértől származó fontos eredményeket. Érthető tehát Poincaré óhaja, hogy magyarországi rövid látogatása alkalmával találkozhasson a fiatal tudóssal. Mit lehetett tenni? Hathatós közbenjárás után, néhány óra múlva egyetlen személykocsiból és mozdonyból álló szerelvény robogott Fejérrel Kolozsvárról Budapest felé..."

Akár hiteles, akár nem, a történet azért is érdekes, mert a kolozsvári matematika akkori állapotát tükrözi. Fejér Lipót nem az egyedüli matematikus volt, akinek tevékenysége jelentősen befolyásolta a XX. század tudományának fejlődését, és aki akkortájt hosszabb-rövidebb ideig a kolozsvári egyetemen dolgozott. Figyelemre méltó, hogy a magyarországi tudományegyetemek közül először nem a budapesti, hanem a kolozsvári vált fontos matematikai centrummá. A háborút megelőző évtizedekben a kolozsvári matematikai iskola a világ legjobbjai közé küzdötte fel magát. Képviselői hervadhatatlan érdemeket szereztek maguknak és a magyar tudománynak. Nem valószínủ, hogy mostanában elmúlik olyan munkanap, amelyen valahol a világon Farkas Gyula, Fejér Lipót, Haar Alfréd vagy Riesz Frigyes neve szóba ne jönne.

Hogyan jutott a XX. század elején e magaslatokra a kolozsvári matematika? Milyen személyi feltételek, társadalmi és gazdasági jelenségek, tudománymüvelési és oktatásfejlesztési stratégiák segítették a fejlődésben? (Bizonyára az erdélyi magyarság mai gondjainak kezelése szempontjából is tanulságos lehet ezekre a kérdésekre adott válasz.) 


\section{Az első évtizedek}

1872-ben, a kolozsvári egyetem megnyitásakor, a matematika szempontjából Erdélyben a helyzet nem volt kecsegtető. A két Bolyai tevékenységétől eltekintve, a kor itteni matematikai irodalma egészen szegényes. A leginkább említésre méltó esemény Brassai Sámuel nevéhez füződik, aki magyarra fordította Euklidész Elemek címü könyvét.

Amikor az újonnan létesített kolozsvári egyetemen a matematikai tanszékek megszervezésére sor került, az erdélyiek közül csak Brassai jöhetett szóba, aki akkor az Erdélyi Múzeum-Egylet igazgatója és a Természettár őre volt. Tudományos hírneve, tekintélye Kolozsváron oly nagy volt, hogy az egyetem ügyével foglalkozó újságcikkek őt a jelöltek között emlegették. Már 1870-ben egyetemi tanárságra pályázott Pesten, és várta, hogy hívják meg a szanszkrit nyelv tanárának. Úgy tudjuk, Brassait báró Eötvös József tanügyminiszter megkérdezte, hajlandó volna-e az alapítandó kolozsvári egyetemen valamilyen tanszéket vállalni. A választást rábízták, de ő több tárgyat jelölt meg, ami utóbb a kinevezéseket eszközlö új tanügyminiszternek, Trefortnak nem kis bajt okozott, "nem könnyen állapodhatván meg abban, melyik tanszékre nevezzék ki". Brassai azt ajanlotta, hogy válasszanak a filozófia, a növénytan, a pedagógia, a müvelödéstörténet, a nyelvtudományok és a matematika közül. Végül kinevezték nyilvános rendes tanárnak az Elemi Mennyiségtan tanszékre, amire - Boros György Dr. Brassai Sámuel élete címü könyve szerint - maga Brassai is a legkevésbé számított.

Brassai Sámuel (1800-1897) Torockószentgyörgyön született. Huszonegy éves korában a kolozsvári Unitárius Kollégiumban végezte a filozófiai tanfolyamot. (Egyetemi tanulmányokat nem végzett.) Néhány évig nevelö, majd 1837-ben a kolozsvári Unitárius Kollégiumban a földrajz és a történelem tanára, később a matematikát és a természettant tanította. 1841-ben németországi tanulmányúton vett részt, azután mint igazgató tért vissza tanári állásába. A szabadságharc után Pesten, majd ismét Kolozsváron tanárkodott.

A Brassai által magyarra fordított Elemek ma is megtalálható a kolozsvári matematikai könyvtárban. Sok tankönyve közül már csak az 1883-ban Budapesten kiadott Algebrai gyakorlatok címü kötete van meg a kar könyvtárában. Akit a magyar matematikai szaknyelv fejlödése érdekel, sokat tanulhat ezekböl a müvekből. Sajnálatos módon nem ismerte fel Bolyai János 
új korszakot nyitó felfedezésének jelentőségét, és nyilvános fellépésével akadályozta annak magyarországi elismerését.

A másik kinevezett matematikus nyilvános rendes tanár Martin Lajos volt a Felsöbb Mennyiségtan tanszéken, aki mérnökként lett 1859-ben az Akadémia levelező tagja.

Martin Lajos (1827-1897) Budapesten született, egyetemi tanulmányait a budapesti Mủegyetemen és a Genie-Akadémián végezte. 1859-ig tartó hadmérnöki pályafutása után 1861-ben budai főmérnök, 1863-68 között középiskolai tanár. Ebben a minőségében, a közoktatásügyi miniszter megbízása alapján, mennyiségtan-, mértan- és ábrázolómértan-tankönyvet írt. 1868-ban a pesti távírda gondnoka, 1869-ben pedig a debreceni távírda helyettes igazgatója. Innen 1871-ben a kolozsvári távírdához igazgatónak nevezték ki. 1872-től haláláig a kolozsvári egyetem Felsőbb Mennyiségtan tanszékének nyilvános rendes tanára. Tudományos tevékenységének középpontjában a repülés kérdése állt. A repülés magyar úttörője. Főbb müvei: A vizszintes szélkerék (Budapest, 1874), Az erömütani csavarfelületek, (Budapest, 1874), A csillagâszat újabbkori haladásáról, (Kolozsvár, 1877), Variátio Számitás, (Kolozsvár, 1879), A madárrepülés általános elmélete (Kolozsvár, 1890). Ezek közül az elsö két mủ egy kötetbe foglalva, valamint a Variatio Számitás a kolozsvári matematikai könyvtárban ma is megtalálható.

A szó szoros értelmében sem Brassai, sem Martin nem volt matematikus. Egyikük sem végzett matematikai kutatásokat, nem ez állt érdeklödésük középpontjában. Viszont mindkettejüket vonzották az alkalmazott matematikai kérdések: az előbbi csillagászattani, az utóbbi pedig repüléstechnikai tárgyú dolgozataival igazolta ezt.

A harmadik matematikai tanszékre, melynek neve Mennyiségtani Fizika volt, csak 1874-ben találtak megfelelő embert a fiatal Réthy Mór személyében. A németországi híres egyetemeken doktori címet szerzett, alapos felkészültséggel és rendkívüli tehetséggel rendelkező fiatal matematikusok, akik a kolozsvári egyetemre kerültek, új lendületet adtak az itteni tudományos életnek. Közülük időrendi sorrendben az első Réthy Mór (1848-1925) volt. Nagykőrösön született, a bécsi, a göttingai és a heidelbergi egyetem hallgatója volt. Ez utóbbi helyen szerzett doktori címet 1874-ben. Már ebben az évben a kolozsvári egyetem rendkívüli tanára, majd két év múlva a Mennyiségtani Fizika Tanszékének nyilvános rendes tanára. 1884-1886 között az Elemi Mennyiségtan Tanszék vezetője. Ezután a budapesti Mü- 
egyetemre ment át. Az elméleti fizika egyik első magyarországi professzora. Külföldön is elismert eredményei az inkompresszibilis folyadéksugár alakjára vonatkoznak. Jelentősek a mechanika elveire és a kémiában szereplő Ostwald-elvre vonatkozó kutatásai. A matematika terén különösen értékesek azok az eredményei, amelyek a Bolyai Farkas által vizsgált végszerüen egyenlő területek kérdésére vonatkoznak. Réthy Mór Kőnig Gyulával együtt rendezte sajtó alá Bolyai Farkas fömüve, a Tentamen második kiadásának első kötetét.

1874-ben előadást tartott Kolozsváron a Bolyai-geometriáról, a legelső ilyen tárgyú előadást az akkori Magyarországon. (Megjegyezzük, hogy a jeles osztrák matematikus, Johannes Frischauf, már az 1871-72-es tanévben kurzusszerü előadásokat tartott a grazi egyetemen a nem euklideszi geometriáról. Ezek tartalmazták Bolyai János zseniális müvének, az Appendixnek első részletező ismertetését. Az előadások 1872-ben Lipcsében könyv alakban is megjelentek Absolute Geometrie nach Johann Bolyai címmel. Ez a könyvecske az első és sokáig az egyetlen olyan tanulmány volt, amely az abszolút geometriát - az Appendixre támaszkodva - elemi úton építette fel. A könyvben viszont nem esik szó azokról a szerkesztési feladatokról, amelyeket Bolyai János a hiperbolikus térben megoldott.)

Az Appendix tanulmányozását Réthy úgy próbálta megkönnyíteni, hogy több definíció (például: a párhuzamosság, paraciklus, paraszféra, hiperciklus és hiperszféra Bolyai-féle értelmezése) olyan átfogalmazását adta, amely az eredetinél jobban követhető. Felhasználva azt, hogy az abszolút geometria végtelen kis térrészében az euklideszi geometria tételei érvényesek, továbbá támaszkodva arra, hogy az állandó görbületủ felületek trigonometriája független az euklideszi ötödik posztulátumtól, Réthy a Bolyai-trigonometriát önállóan is felépítette. Külön érdeme még, hogy az Appendixben található szerkesztéseket legelöbb ő méltatta és dolgozta ki részletesen.

Réthy szószólója volt annak a gondolatnak, hogy a hazai matematikai kutatásoknak a két Bolyai eredményeire kell támaszkodniuk. Ahogy mondta: „hazánkban, ahol eddig a két Bolyain kívül számottevő matematikus nem élt, ezen két férfiú mủködéséböl kell minden további tudományos törekvésnek kiindulni."

Az egyetemnek nagyon keményen kellett küzdenie a kezdet nehézségeivel. Számos, többnyire célszerütlen épületben folyt az oktatás. Az intézetek s az egyetemi könyvtár helyzete szinte kétségbeejtő volt. Igaz ugyan, hogy 
az Erdélyi Múzeum -Egylet összes gyüjteményét, mintegy 30000 kötetből álló könyvtárával együtt, évi ötezer forintért ötven évre az egyetemnek bérbe adta, de az oktatás és a tudományos kutatás céljaira szolgáló szakkönytárak alapjait még ezután kellett lerakni. Az állam kezdetben csak csekély összeggel tudta segíteni az egyetemet. A kolozsvári társadalom maga is „kevéssé buzdult fel, $\mathrm{s}$ az első évben mindössze csupán négy alapítványt tett az ifjúság számára". A tanárok csak hosszas keresgélés után találtak maguknak megfelelő lakást, s a kisvárosban a diákság sem lelt elég szórakozást, ezért "elég zajos mulatságokban keresett kárpótlást".

Ilyen előzmények után nem csoda, hogy az egyetem létesítése után néhány évig a kolozsvári matematika a felzárkózás kényszere alatt állt. A nehézségeket tetőzte, hogy azokban az években valójában az egész magyar matematika hasonló gondokkal küszködött. Az érdekeltek többsége tudta, hogy az egyetem csak úgy töltheti be igazi szerepét, ha ott, az oktatás mellett, magas szintü tudományos kutatás folyik. Ennek ellenére, úgy tűnik, az első években a tanárok között nem volt egyetértés az egyetemi tevékenység céljait és formáit illetően. A kolozsvári Ferenc József Tudományegyetem 1896-ban kiadott története és statisztikája szerint 1878. szeptember 8-án Imre Sándor rektor a tudományos szellem hiányát kifogásolta, hangsúlyozva, hogy az egyetem nem iskola, hanem tudományos intézet, s a kettőt nem szabad összetéveszteni. Ugyanakkor „első és födolognak a tudományok meggyökereztetését $\mathrm{s}$ terjesztését tartván, erélyesen sürgette a középiskolák reformját, hogy az ifjak igazán megfelelő előkészültséggel jöjjenek az egyetemre". A következỏ évi rektorváltás idején a régi rektor büszkeséggel utalt az utóbbi tanévben kétszer tartott pályázati ünnepségre s az egyetemi ifjúság tudományos szorgalmának, önállóságának jeleire, valamint a tanári karnak a nemzeti és egyetemes tudományosság elöbbre vitelében tanúsított és külföldön is elismeréssel fogadott munkásságára. Ezzel szemben Brassai Sámuel, az új rektor „kikelt az ellen, hogy a tanár ne csak maga törekedjék új dologra a tudományban, hanem tanítványait is ez irányban vezesse. $\mathrm{Az}$ egyetemi tanárnak nem az az első és fö kötelessége, hogy újat találjon, s az efféle research iránt való követelőzés felesleges, jogtalan és képtelen. Annál feleslegesebb, jogtalanabb és képtelenebb magukkal a hallgatókkal szemben”. Ezért kifogásolta a pályadijakat „mint a melyek megtestesítései ama, már sokszor elutasított követelménynek, hogy a tanítványt újak fölfedezésére, a tudomány tovább-vitelére kell vezetni”. 
Szerencsére a következö években a kolozsvári egyetemen nem ez a felfogás vált uralkodóvá. Az egyetem egyre nagyobb figyelmet fordított a legtehetségesebb hallgatók alapos felkészítésére és a kutatásba való bevezetésére. A hallgatók számára kiírt kutatási pályázatok évről évre népszerủbbekké váltak, a tananyag pedig fokozatosan közeledett a nyugat-európai szinthez és foglalkozni kezdett a tudomány aktuális problémáival. A legjobbak továbbképzését ösztöndíjakkal segítették. Ugyanakkor az egyetem vezetösége nagy gondot forditott olyan tanárok kinevezésére, akik híres külföldi egyetemeken doktori címet szereztek, és ott elismert tudományos eredményeket értek el. Ezek sok olyan speciális kollégiummal segítették a tehetséges fiatalok fejlódését, amelyek egy-egy divatos diszciplína legmélyére nyúltak, magukba foglalva előadójuk sokszor egészen alapvető eredményeit is. Kolozsváron matematikából a számelmélet, a differenciálegyenletek elmélete, a komplex függvénytan, a vektoralgebra, az analízis, a kvaterniók és az elliptikus függvények tana, valamint a Bolyai-geometria volt elötérben. $\mathrm{Az}$ eredményességet és a színvonalat nemcsak a megjelent néhány monográfia, a sok litografált jegyzet, de a bel- és külföldi folyóiratokban közzétett értekezések egyre nagyobb száma is bizonyítja.

Az állam évröl évre többet költ az egyetemre: az első 15 évben 160000 forintról 279 000-re nőtt a költség. A tanárok tudományos mủködéséről és az egész egyetemről elismerő szavak hangzottak el a sajtóban s az országgyülésen is. Mindezen eröfeszitések ellenére 1876 és 1886 között a matematikus hallgatók száma 67-röl 23-ra csökkent. Az egyetem vezetősége abban látta az okot, hogy éveken át még a jelesebb tanárjelöltek is hiába vártak alkalmazásra. Annak fő okát pedig, hogy a fiatalok nem jönnek nagyobb számban az egyetemre, a város rendkívüli drágaságában kereste.

\section{Új lendülettel}

A XIX. század utolsó évtizedének elején az egyetem életében fontos változások történtek. Ekkorra a tanszékek száma 51-re, a tantestület tagjaié 68-ra, a tanársegédekkel és gyakornokokkal együtt pedig a tudományos alkalmazottak száma 119-re emelkedett. A hallgatóké az első negyedszázadban 233-ról 702-re ugrott. Hasonlóképpen növekedett a matematikusok száma is.

Az épületgondok megoldása végett, Meixner Károly tervei szerint, Reményik Károly kolozsvári építész 1893-ban megkezdte a központi épület 
felépitését. Így 1895-ben Martin Lajos rektor, aki székfoglalójában a repülőgépröl értekezett, immár az egyetem új épületében üdvözölhette az ifjúságot. Ugyanabban az évben Kolozsvár városa az államnak ajándékozta a Bel- és Külső-Torda utca sarkán levő telket, hogy rajta az egyetemnek egészen modern könyvtári palotát emeljen. A századfordulóra az egyetem Erdély szellemi központja, a tudományoknak valóban olyan szentélye lett, ahol - gróf Mikó Imre szavai szerint - „az ismeret, a felvilágosodás és ezáltal a szabadság igéit hirdetik". Mindez, természetesen, elválaszthatatlan attól a társadalmi, technikai és gazdasági fejlődéstől, amely abban az időben Magyarországra - és benne Erdélyre - jellemző volt. Az ekkor kialakuló polgári társadalom igényelte az oktatás és a tudomány fejlesztését. A polgári családokból származó fiatalok egyre nagyobb hányada vonzódott a tudományokhoz. Nem egy fiatalember mondott le biztos megélhetést ígérő karrierjéröl a tudományos pálya kedvéért.

Külön ki kell emelnünk a magyar középiskolai reformok jótékony hatását. Az Eötvös József nevéhez füződő közoktatási törvény és a zsidók emancipációjának kimondása fontos változásokat hoztak a matematika és a fizika oktatása terén is. Az 1890-es évek elejére sikerült kiépíteni egy modern iskolahálózatot, amelyben igényes, hatékony oktatás folyt. Kitűnő középiskolai tanárok jelentek meg, akik fáradságot nem ismerő munkájukkal a fiatalok hosszú seregét nyerték meg a tudománynak.

A középiskolák számára készült új szellemủ Trefort-féle tanterv matematikai részét Kőnig Gyula dolgozta ki. Bírálva a matematikai oktatás addigi eredménytelen módszereit, König így ír: „Kérdeznünk kell, vajon azon a módszertani alapon, mely a középtanodai mathematikai tananyagból elvont, érdektelen és ennek következtében érthetetlen »igazságok« egymásutánját gyártja - melynél a tanuló alig bírja belátni, hogy minek való mind$\mathrm{az}$, amit tanul, $\mathrm{s}$ melynél a cél nem annyira a matematikai gondolkodásmód fejlesztése, mint csak minél több „tétel”-nek félig eröszakos lehozása -, kérdeznünk kell, vajon ezen az alapon lehet-e egyáltalán jobb eredményeket várni?"

Eötvös Loránd (1848-1919) és König Gyula (1849-1913) 1891-ben megalakították a Mathematikai és Physikai Társulatot. A Társulat célját Eötvös Loránd így fogalmazta meg: „Tanuljunk egymástól, hogy mennél jobban taníthassunk." A Kármán Mór (Kármán Tódor világhírü fizikus apja) elgondolásai alapján, a budapesti és a kolozsvári egyetemek mellett felállított tanárképző intézetek és gyakorlóiskolák (ilyen volt például a budapesti 
Mintagimnázium) a tanárképzés színvonalának emelkedéséhez vezettek. A sajátos magyar tanárképzési modell az Eötvös Collegium létrehozásával teljesedett ki. A bentlakásos intézményben tehetséges tanárjelöltek tanulhattak neves tanárok irányítása mellett.

A matematikus- és fizikusképzés szempontjából fontos szerepet játszott a fiatal győri tanár, Arany Dániel által 1893-ban elindított „magyar csoda”, a Középiskolai Matematikai Lapok, amely ma a világon a leghosszabb életü - ilyen jellegü - kiadványnak számít. (A lap szerkesztését három év múlva a budapesti fasori evangélikus gimnázium legendás tanára, Rátz László vette át.) Hamar kiderült, milyen hasznos, ha tehetséges fiatalok éveken át példák tucatjain törik a fejüket, és írják le gondolataikat. A ma hivatalosan KöMaL-nak nevezett lapon nevelkedettek egy része tudós lett, másik része "csak” nagyon jó szakember, tanár. Megoldói közül kerültek ki a XX. század legjobb magyar matematikusai, így azok is, akik az első világháborút megelőző időben világszintre emelték a kolozsvári matematikát.

Kik voltak abban az időben azok a személyiségek, akiknek munkássága meghatározta a kolozsvári matematika fejlődését? Itt alkotott mủveik közül - a folyóiratokban közölt cikkek mellett -, a viszontagságos feltételek ellenére, melyek találhatók még meg Kolozsváron? A vázlatos felelet is képet nyújt arról, hogyan alakult az itteni matematika helyzete az új évszázad küszöbén.

A felsorolást Réthy leghíresebb tanítványával, a Marosvásárhelyen született Vályi Gyulával (1855-1913) folytatjuk, aki a kolozsvári egyetem elsö erdélyi származású, markáns matematikusa volt. Vályi Gyula egyetemi tanulmányait 1877-ben Kolozsváron végezte, majd az egyetem támogatásával négy féléven át Berlinben Weierstrass, Kirchhoff, Kronecker, Borchardt és Kummer elöadásait hallgatta. A másodrendü parciális differenciális egyenletek elméletéhez címü doktori értekezését 1880-ban Kolozsváron védte meg. 1881-ben kezdi meg magántanári működését a kolozsvári egyetemen. 1884-ben a mennyiségtani természettan, majd 1886-ban az elemi mathésis tanára lett. Több fontos publikációja a Mathematikai és Természettudományi Értesitóben jelent meg. Amint Réthy is megjegyzi: „értekezéseinek nem a száma és nagysága, hanem azok minösége imponál." Testi törékenysége gátolta a munkában, ennek ellenére „lelke maradandók alkotására vitte".

A kolozsvári egyetem tanrendje szerint az Appendixről kurzusszerü elöadásokat először Vályi Gyula tartott az 1891-92-es tanév második felében. E népszerü kollégiumát ettől kezdve csaknem változatlan formában 
négyévenként többször megismételte. Az elöadásról készült 102 oldalas litografált jegyzet Bolyai János Appendixéról címmel 1904-ben Kolozsváron jelent meg. Ebben az eredeti bizonyításokat magyarázó részek közbeiktatásával egészítette ki. Az abszolút és hiperbolikus geometria összehasonlítása céljából helyenként Lobacsevszkij eredményeiből is kölcsönzött.

Vályi Gyula buzgó munkásságának is köszönhető, hogy Kolozsvár a Bolyai-kultusz fellegvára lett, és hogy tanítványai közül többen is eredményesen vettek részt a Bolyai-geometria továbbfejlesztésében.

Az Erdélyi Múzeum-Egylet vezetőségében a matematikusokat sok éven keresztül Vályi Gyula képviselte.

Különösen nagy nyeresége volt az egyetemnek Farkas Gyula és a tíz évvel később Kolozsvárra került Schlesinger Lajos, akiknek munkássága döntő módon kihatott az itteni matematikai életre. Nagy szaktekintélyüket és rátermettségüket arra használták, hogy a matematikai oktatás és kutatás feltételeit minél magasabb szinten biztosítsák, a kolozsvári iskola eredményeit mindenhol elismertessék.

Farkas Gyula (1847-1930) Pusztasárosdon született, egyetemi tanulmányait a pesti egyetemen végezte, ahol föleg Jedlik Ányos volt rá nagy hatással. Később Batthyány Géza gróf jóvoltából franciaországi tanulmányúton vett részt. Farkas Gyula fiatalkori matematikai eredményei közül itt csak Bolyai Farkas trinomegyenletekre vonatkozó, a Tentamenben röviden tárgyalt gyökközelítő algoritmussal kapcsolatos vizsgálatait említjük meg. Ezáltal a Bolyai-algoritmus igen ismertté vált; általánosításaival, alkalmazásaival, a vele kapcsolatos konvergenciaproblémák vizsgálatával - a legújabb időkben is - több magyar és külföldi matematikus foglalkozott. Farkas Gyula 1887-ig Pesten magántanár, amikor kinevezik a kolozsvári egyetem rendkívüli tanárának. 1888-ban az egyetem rendes tanára lett, és e minőségében 1915-ig müködött. Ortvay Rudolf, egykori tanársegéde írta róla, hogy "mélyreható kritika, a hajthatatlan, mellékes szempontok által el nem téríthető keresése az igazságnak jellemezte úgy tudományos mủködését, mint egyetemi közügyekben kifejtett tevékenységét ... És épp mivel nem kereste a népszerüséget, igen nagy tekintélyt tudott magának szerezni, és áldás-dús befolyást gyakorolni az egyetemi ügyek vezetésére".

Egyetemi tanárként főleg elméleti fizikai problémákkal foglalkozott, de a vizsgált fizikai problémák matematikai hátterét oly mélységben dolgozta ki, hogy azok között klasszikus matematikai eredmények is vannak. A 1890es évektől kezdve különösképpen a Fourier-féle mechanikai elv foglalkoz- 
tatta. Dolgozataiban egyenlőtlenségekkel adott kötések esetén az egyensúly szükséges feltételét adja meg. Ehhez bebizonyítja a lineáris egyenlőtlenségekre vonatkozó tételét, mely Farkas-lemma néven az egyik legismertebb magyar matematikai eredmény. Ezeknek a munkáknak az alapján ma világosan látjuk, hogy Farkas Gyula egyike a modern optimalizáláselmélet megalkotóinak.

Egyetemi előadásait gondos kidolgozásban litografálva közreadta. A kolozsvári matematikai könyvtárban még ma is megtalálhatók egyetemi jegyzetei: Analytikus mechanika (1907-08), Analitikus mechanika (191314), Erötan (1913- 1914), A mechanika alaptanai (1913-14). Ugyancsak megtalálható a Kolozsváron megjelent Vector-tan és az egyszerü inaequatiok tana címủ könyve. Ez nagyon jól megírt vektoranalízis-könyv, mely tartalmazza kutatásainak fontosabb eredményeit is.

Klug Lipót (1854-1944) Gyöngyösön született. Budapesten matematikából szerzett tanári oklevelet. Pozsonyban, majd Pesten tanított, 1897 től 1917-ig a kolozsvári egyetemen az Ábrázoló Geometria Tanszék tanára. Eközben, nagyszámú értekezés mellett, öt népszerü tankönyve jelent meg: A projektív geometria elemei (Budapest, 1892), Projektiv geometria (Budapest, 1903), Az általános és négy különös Pascal-hatszög configuratiója (Budapest, 1898), Ábrázoló geometria (Budapest, 1900) és A harmadrendü térgörbék synthetikai tárgyalása. Ezek közül az elsỏ négy Kolozsváron ma is megtalálható. Sajnos, egyetemi jegyzetei közül csak egy van meg: Az egyszerü görbe felületek ábrázolása (1909-10).

A századfordulón a kolozsvári egyetem matematikai intézetének külföldön legismertebb tanára Schlesinger Lajos (1864-1933) volt. Nagyszombatban született, középiskolai tanulmányait Magyarországon, egyetemi tanulmányait pedig Heidelbergben és Berlinben végezte. Mint a berlini egyetem magántanára, 1890-ben egy félévet Kolozsváron tanított. A híres berlini professzor, Lazarus Fuchs tanítványa és veje volt, ezért mondták róla, hogy „a tehetséget leginkább a vej örökli.

1897-ben, amikor nyilvános rendes tanárként az egyetemre került, már ismert tudós volt. Lipcsében a Teubner Kiadónál addig napvilágot látott a Handbuch der Theorie der Linearen Differentialgleichungen híres könyvének első két kötete, melyet a berlini egyetem magántanáraként írt. A harmadik kötetet 1898-ban már kolozsvári professzorként jelentette meg. A matematikus társadalom ekkor úgy ismerte őt, mint a differenciálegyenletek komplex függvénytanra épített elméletének egyik meghatározó szaktekintélyét. 
Kevés olyan része van ennek a jelentős elméletnek, amelyet Schlesinger ne gazdagított volna lényegbevágóan új eredményekkel.

Kolozsvárra érkezve, a kutatói munka folytatása mellett nagy lelkesedéssel végezte az egyetemi oktatást. A kolozsvári matematikai könyvtárban ma is megtalálható 15 egyetemi jegyzete. Talán nem érdektelen ezek címeinek felsorolása: Elliptikus függvények elmélete és alkalmazásai (1898-99), Égi testek mechanikája (1898-99), A differentiál-számitás (1900), Riemannféle felületek (1900), Elliptikus függvények (1901), Bevezetés a variatio számításba (1902), A tér abszolúte igaz tudománya (jubiláris előadássorozat Bolyai János születésének 100. évforulójára), Differenciálszámitás (190?), Az abszolút sík eltolásaiból alkotott discontinuus csoportokról (1905), Fucks-féle függvények (1906-07), Égitestek mechanikája (190?), Görbevonalak és felületek elmélete (1907-08), Válogatott fejezetek az infinitesimális geometriából (1908), Égi testek forgásáról (1908-09), Differenciál-egyenletek elmélete (1909-10).

Ezek az előadások lenyügöznek áttekinthető, világos stílusukkal és a tárgykörök akkori legújabb eredményeinek szabatos tárgyalásával. Kétségtelen, hogy a fenti előadások a mindenkori kolozsvári matematikai oktatás csúcsteljesítményeihez tartoznak.

Schlesinger Lajos kolozsvári tudományos munkásságának fontos eredménye a Teubner Kiadónál 1908-ban megjelent Vorlesungen über lineare Differentialgleichungen címủ könyve. Ez nem a fent emlitett Handbuchban kifejtett elmélet átdolgozása, hanem a lineáris differenciálegyenlet-rendszerek teljesen új módszerekkel való tárgyalása. Ez az első monográfia, amelyben a V. Volterra olasz matematikus által értelmezett szorzatintegrál segítségével kezelik a változó együtthatójú lineáris differenciálegyenletrendszereket.

Schlesinger szaktekintélyének elismerését jelenti a Német Matematikai Társaság gondozásában - a Teubner Kiadónál 1909-ben - megjelent Bericht über die Entwicklung der Theorie der linearen Differentialgleichungen seit 1865 címü könyve is. A kolozsvári matematikai könyvtárban megtalálható Automorphe Funktionen című ismert könyvét már mint a giesseni egyetem professzora írta.

A Kolozsváron töltött évei alatt igen sokat tett az itteni matematikai élet fellendítéséért. Farkas Gyulával és Vályi Gyulával együtt döntő szerepe volt abban, hogy az egyetemen kitünő matematikai könyvtár jött létre. 


\section{A Bolyai-centenárium}

1894-ben a Congres international de bibliographie des sciences mathematiques Henri Poincaré elnöklete alatt tekintélyes bibliográfiakiadványt készített elö, amelyben - az eredeti tervek szerint - az egyik fejezet címe Geometrie de Lobatschewsky lett volna. Magyar tudósok egy csoportjának közbenjárására sikerült a fejezet címét Geometrie de Bolyai et Lobatschewskyre módosítani. A szakirodalomban ettől az időponttól kezdve szerepel egyenértékủként - a nem euklideszi geometria kapcsán - a két tudós neve. Miért csak ekkortól? Bolyai János érdemeinek elismerése több okból késett. Kezdődött azzal, hogy Gauss, bár elismerte Bolyai zsenialitását („Ich halte diesen jungen Geometer v. Bolyai für ein Genie erster Grösse" - írja egyik levelében), sajnálatos módon hátrányosan befolyásolta az utókor véleményét az Appendixről. Gauss szerint a nem euklideszi geometria gondolatát ő vetette fel személyes beszélgetéseik alkalmával Bolyai Farkasnak, és ötletét az apa közvetítette Jánoshoz. Hasonló vélekedés Lobacsevszkijjel kapcsolatban is elhangzott; ez esetben Bartelset (Gauss egykori tanárát, aki később Kazányban volt professzor) tartották az új eszmék továbbítójának. A valóság az, amint a Bolyai-hagyaték feldolgozása során kiderült, hogy Bolyai János másoktól függetlenül, önállóan fedezte fel geometriai rendszerét. $\mathrm{Az}$ elismerés késéséért azonban leginkább az akkori magyar matematikusok mulasztásai okolhatók. (Jellemzö, hogy Brassai Sámuel még 1886-ban is elmarasztalóan ír Bolyai művéről.) Ismeretes, hogy a Bolyai-kutatás úttöröi külföldiek voltak. Az Appendixet Hoüel bordeaux-i professzor már 1867ben franciára fordította és - Schmidt Ferenc temesvári építész Bolyai-életrajzával kiegészítve - megjelentette. Battaglini gondozásában ugyanabban az évben jelent meg az olasz fordítás is, a német nyelvü ismertetés pedig, amint emlitettük, 1872-böl származik. Halsted texasi professzor közremüködésével 1891-ben megjelent az angol nyelvü változat is. A magyar tudomány képviselöi csak a külföldi kezdeményezések hatására döbbentek rá, hogy e téren adósságaik vannak. Hosszas huzavona után 1897-ben az Appendix végre megjelent magyarul is. Ilyen előzmények után érkezett el Bolyai János születésének 100. évfordulója.

A centenáriumi ünnepségeket Kolozsváron az esemény jelentőségének megfelelően készítették elő. Az egyetem matematikai és természettudományi kara 1899. december 29-én tartott ülésén elhatározta, hogy annak a napnak a 100. évfordulóján, amelyen Bolyai János született, szülőházát em- 


\section{EME}

léktáblával jelölik meg, ünnepélyes megemlékezést tartanak és emlékiratot bocsátanak ki, amelyben felvázolják a Bolyai-geometria hatását a matematika fejlődésére a XIX. században.

A centenáriumi ünnepségek megszervezésében a föszerepet Farkas Gyula és Schlesinger Lajos játszotta.

Bolyai szülőházát Schlesinger Lajos kutatta fel. Ez a ház ma Kolozsvár egyik nevezetessége, ezért talán nem érdektelen, ha az azonosítás körülményeire is kitérünk. A kérdéses ház felkutatására az első támpontot Bolyai Farkasnak 1802. szeptember 11-én Domáldról kelt, Gausshoz intézett levele szolgáltatta, melyben a címet így adja:

„Meine Adresse: Mr. Wolfg. Bolyai

Bodor Pál urnal

a belső közép utczában."

A következő leveleken is ez a cím szerepel 1804. szeptember 16-ig, amikor Farkas közli a marosvásárhelyi címét. Valószínủnek látszott, hogy Bolyaiék kolozsvári tartózkodása alatt, vagyis 1802 őszétől 1803 tavaszáig, a Belközép utcai Bodor-féle házban laktak, és János ebben a házban látott napvilágot. Több kolozsvári lakos (ezek közt Bodor László királyi táblabíró, Bodor Pál unokája), valamint Bolyai Farkasnak Bodor Pálhoz intézett és Bodor Pál hátrahagyott irattárában örzött más levelek tanúsága szerint azonban kitünt, hogy Bolyainé (Benkö Zsuzsanna) szüleinek saját házuk volt. Ezt a házat Farkas anyósa, özvegy Benkő Józsefné megbízásából Bodor Pál 1816-ban nyilvános árverésen eladta Szenkovits Jakabnak. Schlesinger arra a következtetésre jutott, hogy Bolyaiék kolozsvári tartózkodásuk idején nem Bodor Pál házában, hanem a szintén a Belközép utcában fekvő, akkor Benkö József tulajdonát képezö, 1816 óta pedig a Szenkovits-féle házban laktak, és ebben a házban látott Bolyai János napvilágot. Hogy Bolyai Farkas leveleit kolozsvári tartózkodása idején, éppen úgy, mint mikor még Domáldon lakott, Bodor Pál barátjához címeztette, egyszerüen azzal magyarázható, hogy szükségtelennek látta Gausst rövid időre címváltozással megterhelni, mivel kolozsvári lakása a Bodor Pál lakásához oly közel volt, hogy az oda érkezett levelekhez időveszteség nélkül hozzájuthatott. A Bolyai-Bodor levelek alapján Schlesinger kizárásos alapon megállapítja: „Marad tehát mint egyértéküleg meghatározott ház a Tivoli és belközéputcza fötér felöli sarkán fekvő, jelenleg a kereskedő társulat birtokában levő ház , mely, mivel csak a Tivoli-utcza felől bír bejárattal, Deák Ferencz-utczai számot nem visel, hanem Tivoli-utczai 1 . számot .... E szerint tehát bebizo- 
nyítottnak tekinthető, hogy a jelenleg Tivoli utcai 1. számú ház Bolyai János szülöháza".

A latin nyelvü, bőrkötéses emlékirat szép kivitelezésben készült el, melynek címe: Libellus post saeculum quam Joannes Bolyai de Bolya anno MDCCCII a.d/ XVIII Kalendas Januarias Claudiopoli natus est, ad celebrandum memoriam eius immortalem ex consilio Ordinis Mathematicorum et Naturae Scrutatorum Regiae Litterarum Universitatis Hungariae Francisco-Josephinae Claudiopolitanae editus, Claudiopoli, MCMII.

A könyv Bolyai János 1823-ban apjához írt híres temesvári levelének latin fordítása mellett három dolgozatot tartalmaz, melyek közül az első kettő 1903-ban az Acta Universitatisban (magyar fordításban) is megjelent. Ezek a következők:

Schlesinger Lajos (Kolozsvár): Az abszolút geometriának a komplex változó függvényeinek elméletére való némely alkalmazásáról.

Stäckel, Paul (Kiel): A többméretü sokaságok mechanikájáról.

Bonola, Rober (Pavia): Az abszolút geometriával kapcsolatban 1839 és 1902 között megjelent dolgozatok jegyzéke.

Az egyetemi tanács 1902 novemberében úgy döntött, hogy Bolyai János születésének 100. évfordulóját 1903. január 15-én ünnepli, tekintettel arra, hogy a távolból érkező vendégek számára nehézségekkel járt volna a december közepi utazás. Az ünnepségek megrendezésére négytagú bizottságot alakítottak, melynek tagjai Szabó Dénes (elnök), Farkas Gyula, Apáthy István és Schlesinger Lajos. Emlékbeszéd tartására Schlesinger Lajost kérték fel. A Magyar Tudományos Akadémia 1902. november 22-én báró Eötvös Loránd vezetése alatt az ünnepségekre küldöttséget nevezett ki, melynek tagjai Szily Kálmán, Réthy Mór, Kürschák József és Tötösy Béla voltak.

A kitűzött napon délelőtt 10 órára az új egyetemi épület aulája megtelt a tudományos intézetek és társulatok küldötteivel, Kolozsvár hivatali és értelmiségi kitünőségeivel, „diszes hölgy közönséggel” és ifjúsággal. A történész-rektor a kor stílusának megfelelően nyitotta meg az ünnepi gyülést: „1802. december 15-én parányi csillag vonult ki városunk láthatárán, hogy rövid pályafutása alatt hazai kultúránk, az egyetemes tudomány egén, mint elsőrangú fényesség tündököljön; hogy bevilágítson oda, hova emberi szem még nem tekintett. Bolyai János föltárta ama rejtelmeket, amelyek 2000 éven át annyi fényes tehetséget sodortak útvesztőbe." 
Az elnöklő rektor sorra felkérte szólásra a küldöttségek szónokait, akik üdvözlő beszédeiket a következő sorrendben mondták el: báró Eötvös Loránd, az MTA elnöke, dr. Frölich Izidor a budapesti Királyi Magyar Tudományegyetem részéről, dr. Beke Manó a budapesti egyetem bölcsészeti kara nevében, dr. Rados Gusztáv a budapesti Királyi Magyar József Mủegyetem nevében, Budisavlievic Emánuel alezredes a bécsi Császári és Királyi Müszaki Katonai Akadémia képviseletében, dr. Kürschák József a Matematikai és Fizikai Társulat nevében, Csíki Lajos a marosvásárhelyi Evangélikus Református Kollégium képviseletében, dr. Szamosi János az Erdélyi Irodalmi Társaság nevében, és végül hozzászólt Bedöházi János, a két Bolyai életrajzírója. A szónoklatok láthatóan mély benyomást gyakoroltak a közönségre, mely lelkesült éljenzéssel nyilvánította ki tetszését. A hozzászólókon kívül az eseményre számos intézet és társulat küldte el képviselöit. Az ünnep alkalmával táviratban fejezte ki üdvözletét a göttingai Matematikai Társulat, levélben a Matematikusok Német Egyesülete és a selmecbányai Bányászati és Erdészeti Akadémia.

Mint tudjuk, a centenáriumi ünnepségeken jelentették be a Bolyai-dij létrehozását. A kezdeményezők König Gyula, Rados Gusztáv, Kürschák József, Farkas Gyula és Schlesinger Lajos voltak. Ezzel kapcsolatban Szily Kálmán, az MTA főtitkára a következő jelentést terjesztette elő: „Bolyai János születése 100. évfordulója ünnepléséhez az MTA azon határozatával járul hozza, hogy a halhatatlan tudósnak, valamint az ö mélyen gondolkozó atyjának és a tudományban mesterének emlékezetére első ízben 1905ben és azután minden 5 . évben a decemberi összes ülésen, a megelőző 5 évben bárhol és bármely nyelven megjelent legkiválóbb matematikai vizsgálat szerzőjét, tekintetbe véve az illetőnek előbbi tudományos müködését is, 10000 korona Bolyai-jutalommal és éremmel tünteti ki. Az érem egyik oldalát az MTA és Budapest képe, másik oldalát magyar felirat diszíti."

Sajnos a dijat csak két alkalommal lehetett odaítélni. Az első világháború idején megszakadtak a nemzetközi tudományos kapcsolatok, a pénz is elértéktelenedett, és a szép kezdeményezésnek nem volt folytatása.

A Bolyai - geometria, amint egyetemi jegyzeteiböl is kitünik, Schlesinger Lajos szívügye volt, ezért nem véletlen, hogy őt kérték fel Bolyai János születésének centenáriumi ünnepségén az emlékbeszéd megtartására. Erre ő nagyon alaposan felkészült. Szép és tartalmas előadásában fontos érveket sorakoztatott fel a Bolyai-Lobacsevszkij-geometria prioritási vitájában, nagymértékben hozzájárulva Bolyai János lángelméjének elismertetéséhez. 
Az emlékbeszéd elhangzása után kiosztották az emlékkönyv néhány példányát, majd a rektor felhívására az ünneplő közönség Bolyai János szülöházához vonult, hogy jelen legyen a Matematikai és Természettudományi Kar által e ház Deák Ferenc utca felőli homlokzatán elhelyezett emléktábla leleplezésénél. A helyszínen Farkas Gyula (akkori dékán) mondott beszédet. Ebben többek között elmondta, hogy „a táblán Bolyai Jánost Magyar Euklidesnek mondjuk, mert a geometriának az alkotó mestere volt, mint Euklides. Atyját, Bolyai Farkast is megnevezzük a táblán, mert mint a Tentamen mély gondolkodású szerzője megérdemli ezt, mihez járul, hogy atya volt ő János matematikai tehetségének fejlesztésében is".

A tábla szövege a következő: „Az 1802. év 12. havának 15. napján, itt született Bolyai János, a Magyar Euklides, bolyai Bolyai Farkasnak, a Tentamen mély gondolkodású szerzöjének fia, minek az emlékezetére száz év múltán a Ferencz József Tudományegyetem matematikai és természettudományi kara állítá e követ."

A Bolyai-díj létesítésével egyidejüleg az Akadémia pályázatot írt ki a Bolyai-Lobacsevszkij-geometriát tárgyaló monográfia megírására. Nem tudjuk, mi lett a kiírás következménye. Schlesinger Lajos 1902-ben $A$ tér abszolúte igaz tudománya címmel a kolozsvári egyetemen előadássorozatot tartott, és - Szénássy Barna szerint - ez lett volna a pályázatra készített monográfia alapja. A kézirat, helyenként alig olvashatóan, ma is megtalálható a kolozsvári egyetem matematikai könyvtárában. Kiadása tudománytörténeti szempontból rendkívül fontos volna.

Kétségtelen, hogy a Kolozsváron megrendezett centenáriumi ünnepségek jelentették Bolyai János végleges győzelmét nemcsak külföldön, hanem saját hazájában is.

\section{A csúcs}

Farkas Gyula - máig ható tudományos tevékenysége mellett - meghatározó szerepet játszott abban, hogy a kolozsvári Matematikai Intézet, szinte a semmiből indulva, az egyetemalapítás után alig negyedszázaddal a Monarchia legkiválóbb tudományos mühelyei közé emelkedett. A tudomány iránti elhivatottsága, nagyszerủ emberi kvalitásai következtében tanártársai és tanítványai körében egyaránt nagy tekintélynek örvendett, melyet az egyetemi ügyek intézésében érvényre is juttatott. Hétszer volt dékán és egy ízben az egyetem rektora is. Szava mindenben döntő volt. Igényes 


\section{EME}

volt, sokat kívánt magától és másoktól is. Az emberi értékeket igen nagyra becsülte, és sokat tett azokért, akiket arra érdemesnek tartott. Befolyását arra használta, hogy az egyetemi tevékenység anyagi és személyi feltételei minél jobbak legyenek. Kifejezetten az ő közbenjárására kerültek a kolozsvári egyetemre olyan ragyogó képességü fiatal matematikusok, mint Fejér Lipót (1905), Riesz Frigyes (1911) és Haar Alfréd (1912), akik az idősebbekkel együtt a XX. század első évtizedeiben olyan minőségi szintre emelték a kolozsvári matematikát, melyet - ha a tanárok nemzetközi presztízsét tekintjük - nehéz lesz valaha túlhaladni.

Fejér Lipótnak címzett alábbi leveleiből is kitünik, hogy Farkas Gyula mennyire szivén viselte a honi matematika és fizika ügyét. (Ezeket a leveleket Prékopa András közölte Farkas Gyula élete és munkásságának jelentősége az optimalizálás elméletében címủ dolgozatában; lásd a Komlósi Sándor és Szántai Tamás által szerkesztett Új utak a magyar operációkutatásban. In memoriam Farkas Gyula. Dialóg Campus Kiadó, Budapest - Pécs, 1999. c. kötetet.)

Miután sikerült Fejér Lipótot a kolozsvári egyetemre kineveztetni, 1905. július 9-én a következő levelet írta:

Tekintetes Dr. Fejér Lipót úrnak

Tégla utca, Kolozsi ház, Gödöllö,

Kedves Doctor Ür!

Örömmel látom szívesen hozzám intézett soraiból, hogy a lehetö legjobb helyen, most a családi tüzhely mellett tölti azt az idejét, amelyben az Alma Mater közvetlenül nem osztozhatik. De tudom, hogy kerülön ebböl is kijut majd közös otthonunknak az a része, akár pihenve, akár munkában töltse azt a kedves doctor úr, elsố esetben az eröszerzés, másodikban az ismeretszerzés és ismeretközlésnek a révén ... Melegen üdvözlöm kedves doctor, de adjon üdvözletemböl kedves hozzátartozóinak is. Ki váltig szeretettel gondolok múlt és jövendö együttlétünkre.

Farkas Gyula.

Az 1911. október 1-én írt levelében Farkas Gyula már Riesz Frigyes Kolozsvárra hozatalával foglalkozik: 


\section{EME}

Kiválóan tisztelt Kedves Tanártársam!

... Kérem azonban, hogy sziveskedjék vélem közölni Riesz Frigyes lakcimét, hogy a helyettesités ügyének eldöntése után lehetö közvetlenséggel fordulhassak hozzája.

Igaz barátja, Farkas Gyula.

Egy névjegykártya hátára 1911. október 3-án ezt írta:

Nagyságos Dr. Fejér Lipót

Tud. Egyetemi ny. r. Tanárnak

Budapest, Vörösmarty utcza 19, földszint 1. lakosztály

A bizottság tegnap javaslatomat magáévá tette, s a rendes tanszék helyettesitésére meg a szeminárium ügyvezetö igazgatására Riesz Frigyes fölkérését javasolja. Kari ülés holnapután.

A következő levél keltezése 1911. október 20.

Nagyságos Dr. Fejér Lipót

ny. rendes egyetemi tanár úrnak

Budapest VII, Vörösmarty utcza 19, földszint 1. lakosztály

Fölöttébb Tisztelt és Kedves Tanártársam!

A mai napon Riesz Frigyes új társunk megérkezett; délben a dékáni hivatalban találkoztunk véle a dékán, Vályi meg én, s immár a matematikai szemináriumok vezetését is kezébe adtuk. Nyomban megírta a fekete táblánkon elöadásainakés gyakorlatainak a hirdetését, 23-án megkezdi előadásait. Most már bizonyos jótékony megnyugvás szállotta meg árvaságunkat. Haar felöl irt szives értesitését vételekor azonnal közöltem a dékáni hivatallal...

Legmelegebb üdvözleteim ismétlésével

igaz barátja, Farkas Gyula.

Miután 1911 nyarán a kolozsvári egyetemröl Schlesinger Lajos is távozott, Farkas Gyula figyelme Haar Alfréd felé fordult. 1911. november 4-én a következő levelet írta: 
Nagyságos Dr. Fejér Lipót

tud. egyetemi tanár úrnak

Budapest, Nádor u. 51. V. Em.

Kiválóan Tisztelt és Kedves Tanártársam!

Íme Riesz Frigyes társunk már javában megkezdte itteni müködését nagy lelkesedéssel a math. szeminárium körül is ... Tegnap levelet kaptam Haartól. Uúgy látszik ebböl, hogy meghivójában, mint a tanszéki bizottság kari referense meg lettem nevezve. Következöleg válaszomban jónak láttam kissé körvonalazni a lényeget. Egyébiránt Haar levele oly mély hazafias érzelmeket árul el, hogy most már nem is tartok attól, hogy ha egyszer haza került, elveszitsük a külföldnek ...

Boldog életet kivánok új lakásában

igaz barátja, Farkas Gyula.

Kolozsvári évei alatt Fejér Lipót, később pedig Riesz Frigyes egyik fontos feladata a Matematikai Szeminárium ügyvezető igazgatása volt. Ezt a szemináriumot, melynek igazgatói Farkas Gyula, Schlesinger Lajos és Vályi Gyula voltak, 1901-ben létesítették. Az ügyvezetö igazgatói teendőket 1905-ig Schlesinger látta el.

Kik voltak az új hullám fent említett képviselöi?

Fejér Lipót (1880-1959) Pécsett született. Középiskolás korában egyik legsikeresebb megoldója volt a Matematikai Lapok feladatainak. 1897ben a Matematikai és Fizikai Társulat versenyén második helyezést ért el. Ugyanebben az évben beiratkozott a Budapesti Múegyetem gépészmérnöki szakosztályába, egy szemeszter után azonban átlépett az ún. egyetemes szakosztályba mint a matematika- és fizikatanári szak hallgatója. Itt főleg Kőnig Gyula, Kürschák József és Rados Gusztáv elöadásait hallgatta, majd átkerült a Budapesti Tudományegyetemre. Az 1899-1900-as tanévet a berlini egyetemen töltötte, ahol Fuchs, Frobenius és Schwarz előadásait látogatta. Hazatérve, az 1900-1901-es tanévet ismét a budapesti egyetemen töltötte. Ezalatt publikálta a párizsi Comptes Rendus-ben a Fouriersorokkal kapcsolatos tételét, ami nevét világszerte egy csapásra ismertté tette. Tanári szakdolgozatát matematikából a Fourier-sorokról, fizikából pedig a fényelhajlásról írta. 1901. szeptember 1-től repetitor volt a budapesti egyetemen, majd 1902 tavaszán megszerezte a bölcsészdoktori címet. 
Az 1902-1903-as tanév első felét Göttingában töltötte, ahol föleg Hilbert és Minkowski előadásait hallgatta. E tanév második szemeszterét Párizsban töltötte, Picard és Hadamard előadásait látogatva. 1905-ig kilenc közleménye jelent meg, melyböl három a már említett Comptes Rendus-ben, egy pedig a Mathematische Annalenben. Ilyen előzmények után - Farkas Gyula szavait használva - senki sem szerette volna „elveszíteni őt a külföldnek”. A kolozsvári egyetem lehetőséget biztosított számára az elölépésre. A Mennyiségtani Természettan Tanszéken (melynek egyedüli tagja Farkas Gyula volt) repetitorként alkalmazták. Ebben ragyogó matematikai tehetségének tanúbizonysága mellett annak is szerepe lehetett, hogy korábban fizikát is tanult, és érdeklődéssel fordult az elméleti mechanika felé. Miután 1905. június 23-án a Ferenc József Tudományegyetem Matematikai és Természettudományi Karán Stabilitási és labilitási vizsgálatok a tömegpontrendszer mechanikájában címủ dolgozatával habilitált, karrierje gyorsan ívelt felfelé. Az 1905-1906-os tanév első felében Schlesinger Lajos tanársegéde, a második szemeszterben már az analízis $\mathrm{s}$ az analitikai mechanika magántanára, 1906 szeptemberében adjunktus lett, 1911-ben pedig nyilvános rendkívüli tanár. A kolozsvári egyetemen tevékenységét ez év nyarán befejezte, mert szeptembertől a budapesti egyetem nyilvános rendes tanára lett. 1908-ban a Magyar Tudományos Akadémia levelező tagjává választották. Kolozsvári évei alatt mintegy 30 tudományos értekezést közölt, többnyire híres matematikai folyóiratokban. Ezek Fourier-sorokkal, elméleti mechanikával és analitikus függvényekkel foglalkoznak.

Riesz Frigyes (1880-1956) 1912 és 1919 között vezette a Felsőbb Mennyiségtan Tanszéket, Györött született, és igen gondos nevelésben részesült. A középiskolát a bencés rend győri gimnáziumában végezte, egyetemi tanulmányait pedig a Zürichi Mủegyetemen kezdte. A tudományos hivatás utáni vágya azonban győzedelmeskedett a biztosabb megélhetést nyújtó mérnöki pálya vonzerején, és tanulmányait 1899-től a Budapesti Tudományegyetemen folytatja, majd egy évet tölt Göttingában. Budapesten Kőnig Gyula és Kürschák József, Göttingenben Hilbert és Minkowski elöadásai voltak rá a legnagyobb hatással. 1902-ben Budapesten avatják doktorrá. Első nagy tudományos felfedezését, az ún. „Riesz-Fischer tétel”-t, huszonhétéves korában publikálta. Később e tétel segítségével mutatták ki a kvantummechanika két felépítése, a Schrödinger-féle hullámmechanika és a Heisenberg-féle mátrixmechanika azonosságát. Riesz nevéhez füződnek a ma széles körben használt p-edik hatványon integrálható függvények 


\section{EME}

terének felfedezése, a folytonos függvények halmazán értelmezett lineáris funkcionálok Stieltjes-integrál alakjában való ábrázolása, valamint a Hilbert-terek duálisának meghatározása. 1908-ban a római nemzetközi matematikai kongresszuson tartott előadásában megalapozta a topologikus tér fogalmát. Ezek a fiatalkori felfedezései hamar világhírüvé tették, még mielött Kolozsvárra került volna.

Egyetemi jegyzetei közül Kolozsváron ma csak három található meg: Függvénytan (1911-12), Fourier-féle sorok (1913-14) és Függvénytan (1914-15). Ugyancsak megtalálható a Riesz kolozsvári évei alatt Párizsban megjelent Les systemes d'équations linéaires a une infinité d'inconnues címú könyve, amely jelentős szerepet játszott a funkcionálanalízis fejlődésében. Kolozsvári mủködése idején egy tucatnyi fontos értekezést közölt.

Riesz Frigyes nemcsak a legkiválóbb magyar matematikusok egyike, hanem világviszonylatban is azok között tartják számon, akik a matematikai analízis modern ágainak megalapozására és kifejlesztésére a legnagyobb hatással voltak. Az általa bevezetett fogalmak, kidolgozott módszerek, a neki köszönhető eredmények a valós függvénytan, a funkcionálanalízis és az általános topológia klasszikussá vált anyagához tartoznak. Ezeknek az eredményeknek egy részét tartalmazza a Szőkefalvi-Nagy Bélával közösen írt Leçons d'analyse fonctionnelle címü híres könyve, amelyet több nyelvre lefordítottak, és a világon mindenhol ismernek.

A mai Magyarország területéröl Kolozsvárra került kiváló fiatal matematikusok sorát Haar Alfréd (1885-1933) zárta. Budapesten született, és a Fasori Evangélikus Főgimnáziumban érettségizett, ahol Rátz László, a Középiskolai Matematikai Lapok volt neves szerkesztője tanította matematikából. Ennek a lapnak Haar is szorgalmas munkatársa volt középiskolás korában. Az előző évben érettségizettek számára évenként tartott országos Eötvös Loránd matematikai versenyen 1903 őszén Haar Alfréd nyerte az első díjat. Egyetemi tanulmányait Budapesten és Göttingában végezte. Budapesten Beke, Eötvös, Frölich, Kürschák, Rados, Scholtz, Göttingában pedig Carathéodory, Hilbert, Klein, Minkowski, Prandtl, Runge, Schwarzschild, Voigt és Zermelo előadásain, illetve szemináriumain vett részt. Hilbertnél doktorált 1909-ben. Ezt követően magántanár Zürichben a műegyetemen. 1912-ben a kolozsvári egyetem egyik matematikai fizika tanszékére nevezték ki, először nyilvános rendkívüli tanárrá, majd 1917-ben nyilvános rendes tanárrá. Haar Alfréd munkássága a matematika legújabb fejlődésére elismerten nagy hatással volt. Benne a tehetség az igazi tudós lelkiisme- 
retességével párosult. Kutatómunkássága igen széles területre terjedt ki. Az ortogonális függvényrendszerekkel, a variációszámítással, a szinguláris integrálokkal, a halmazelmélettel, a függvényapproximációval, a lineáris egyenletekkel és a topologikus csoportokkal kapcsolatos eredményei ma is világhírüek. A Haar-féle bázis, a Haar-tulajdonságú függvényrendszerek, de különösen a Haar-integrál fogalma végleg bevonult a matematikusok mindennapi eszköztárába. Haar eredményeinek mai hatását ékesen bizonyítják azok az előadások, amelyek 1985-ben a centenáriumi tudományos értekezleten hangzottak el, és az Alfred Haar Memorial Conference címü kötetben olvashatók.

Haar Alfrédtöl könyv nem jelent meg, azonban több igen gondosan megírt jegyzetet készített, amelyek sok eredeti részletet tartalmaznak, s mint egyetemi tankönyvek ma is beválnának. Sajnos, ma ezek közül Kolozsváron csak négy található: Differential-Gleichungen (Göttingen, 1911), Algebra (1912-13), Determinánsok és quadratikus formák (1912-13), Számelmélet (1915-16).

\section{Szép város Kolozsvár}

Végül szóljunk arról is, milyen város volt Kolozsvár száz évvel ezelőtt? Passuth László Kutatóárok címü önéletrajzi regényében felvillant néhány emlékképet a város akkori hangulatából. „Úgy idézem vissza a várost, mint amelyet egyik oldalon a Monostor, a másikon a Hóstát zöld övezete határol. A Hóstát két végtelenbe nyúló főutcája mellett ... néhány ezer főnyi parasztság »corpus separatum«-ként élt. Elég sok vasutas tömörült telepekbe, kevés kisebb gyárüzem volt ... Viszonylag sok volt a bank, az egyházi intézmény, de mindent felülmúltak az iskolák. A nem városi eredetü diákok özönlése szeptembertől júniusig tartott, s rengeteg kosztot adónak, szabónak, kvártélyosnak juttatott kenyeret. Szemináriumokon töltötték a bölcsességet mezei jogászok fejébe, s viszonylag színes volt a város »éjszakai « élete is ... Ipari munkásság csekély számban élt, s nem emlékszem arra, hogy bérkövetelések, sztrájkok vagy munkanélküliség formájában éreztünk volna társadalmi feszültséget. A szociális eszmék elsősorban elméleti forrásokból közelítettek: egyetemi professzorok "radikalizálódtak" ... erös volt a Munkásbiztositó Pénztár (Kun Béla is itt dolgozott) ... a sokféle vallás együttélése feltételezett bizonyos türelmességet, melyben nem volt sok helye a vaskalaposságnak. Mert talán sehol Magyarországon nem volt 
olyan tarka a lakosság vallási megoszlás szerinti térképe akkor, mint ebben a városban, ahol a föiskolák egy része is felekezeti formákban élt tovább. A többség katolikus volt, de a város törzsökös lakosságának komoly hányada kálvinista. A lutheránusok inkább szász ajkúak. ... Az unitáriusok egyetlen püspöksége is itt volt. ... Két "görög " templom osztozott a román híveken: a görög-katolikus és a görög-keleti. A háború elött patrícius zsidóság élt a városban, neológ életformák között. A biedermeier város a maga apró szellemi vulkánjaival alapjában provinciális pletykafészek volt, bár a városlakók távolról sem ismerték úgy egymást, mint más - ötven-hatvanezer lakosú városban. Ennek oka az állandó népcserélödés volt, elsősorban a középosztályban: nagyszámú tisztviselő telepedett be, vagy vándorolt el, a hivatali lét mozgástörvényei szerint."

A városközpont akkoriban nyerte el mai arculatát, 1902-ben helyezték talapzatára Fadrusz János remekmúvét, a Mátyás-szobrot.

A New York Szálló nagykávéháza volt a társadalmi és szellemi élet központja. A teremben két hosszú különasztal volt, ahol egyetemi tanárok s mágnások jól megfértek egymás mellett. Sürün ültek össze, poharaztak, közösen vonultak a „művészasztalokhoz”. Ott a Nemzeti Színház színészei, írók, újságírók vertek hagyományszerü tanyát. „Van itt Kolozsvárt egy néhány nyakas, javíthatatlan idealista. Kifinomodott ízlésü, müvészi hajlandóságú emberek. Van közöttük piktor is, szobrász is, építész is, író ember is" - írja az Ellenzék 1905. január 3-án. A város sajátos, történelmi légköre, s ugyanakkor szellemi avantgardizmusa éreztette hatását ezeken az összejöveteleken. A szájhagyomány szerint Fejér Lipót törzsvendég volt a New York kávéházban. Igy találkozott egy tarokkparti sodrában Passuth anyjával is, aki nagyjából egyidős volt vele. Passuth elbeszélése szerint, játék után az ifjú professzor megkérdezte az anyjától, miért nem iratkozik be az egyetemre, s felajánlotta, hogy vállalja matematikai elökészítését ... Egyébként Fejér szellemi érdeklődése a matematikán messze túlterjedt. Szenvedélyesen szerette a zenét, és maga is jól zongorázott. Muzsikusok és írók éppúgy nagyra tartották ítéleteit, mint esztéták és jogfilozófusok. A New York kávéházban többször találkozott Ady Endrével is. Barátságukat Ady neki ajándékozott arcképén a dedikáció melegsége illusztrálja.

A Farkas utca volt a tudomány és a múzsák közös szentélye, gyönyörü gesztenyesorral. Egyik végében az egyetem fóépülete, mellette a régi kőszínház, velük szemben a piarista gimnázium, a másikban pedig a református kollégium és a torony nélküli református templom. Ezek az épületek, 


\section{EME}

a köréjük társult intézményekkel együtt, mintegy megszabták e nevezetes városrész hangulatát. Ebből az utcából tértek be nagy matematikusaink munkahelyükre, az egyetem föépületébe.

\section{Epilógus}

1919-ben a kolozsvári egyetem román fennhatóság alá került, ezért a tanárok nagy része - köztük Haar Alfréd és Riesz Frigyes - Szegedre ment, ahol új egyetem alapjait rakták le. Közben a magyar „matematikusokat gyártó szerkezet" tovább müködött. Kevéssel a háború befejezése után a tudomány olyan müvelői jelentek meg Magyarországon, mint Kármán Tódor, Pólya György, Szegő Gábor, Neumann János és mások. Ök viszont már nem a Kárpát-medence keleti régiói felé vették útjukat, mint néhány évvel elöttük járó társaik, hanem ... - de ez már egy másik történet. 